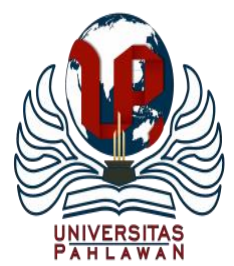

Jurnal Abdidas Volume 2 Nomor 4 Tahun 2021 Halaman 889-893

JURNAL ABDIDAS

http://abdidas.org/index.php/abdidas

\title{
Extensive Reading untuk Pembelajar Bahasa Inggris
}

\author{
Rini Lindawati \\ Pendidikan Bahasa Inggris, FKIP, Universitas Islam Majapahit, Indonesia \\ E-mail : rinilindawati@unim.ac.id
}

\begin{abstract}
Abstrak
Minat membaca pembelajar Bahasa Inggris dikategorikan rendah di Indonesia. Bahkan bisa dikatakan mereka tidak suka membaca. Ketidaktahuan terhadap kosakata Bahasa Inggris dijadikan alasan untuk tidak membaca. Extensive reading adalah salah satu metode yang dapat meningkatkan minat baca dan penguasaan kosakata dalam Bahasa Inggris. Karena hal tersebut di atas, tujuan kegiatan pengabdian masyarakat ini adalah untuk mengenalkan extensive reading kepada pembelajar Bahasa Inggris, sehingga mereka dapat mengaplikasikan dan dapat mencapai tujuan dari extensive reading itu sendiri yaitu kesenangan membaca teks berbahasa Inggris. Metode yang digunakan dalam kegiatan pengabdian ini adalah web-seminar (webinar), ceramah, dan diskusi melalui platform Zoom Cloud Meeting. Total peserta sebanyak 45 orang. Pertama, post-test tentang extensive reading. Kedua, penyampaian materi tentang extensive reading untuk pembelajar asing. Ketiga, kegiatan diskusi terkait extensive reading. Keempat, post-test tentang extensive reading untuk pembelajar Bahasa Inggris. Dengan adanya kegiatan ini, peserta dapat untuk melatih keterampilan membaca dan meningkatkan minat baca teks berbahasa Inggris.
\end{abstract}

Kata kunci: extensive reading, pembelajar bahasa inggris, pengabdian masyarakat

\begin{abstract}
Interest in reading English learners is categorized as low in Indonesia. We could even say they don't like reading. Ignorance of English vocabulary is used as an excuse for not reading. Extensive reading is one method that can increase reading interest and vocabulary mastery in English. Because of the above, the purpose of this community service activity is to introduce extensive reading to English language learners, so that they can apply and achieve the goal of extensive reading itself, which is the pleasure of reading English texts. The methods used in this service activity are web-seminars (webinar), lectures, and discussions through the Zoom Cloud Meeting platform. A total of 45 participants. First, post-test on extensive reading. Second, the delivery of materials on extensive reading for foreign students. Third, discussion activities related to extensive reading. Fourth, post-test on extensive reading for English learners. With this activity, participants can practice reading skills and increase interest in reading English texts.
\end{abstract}

Keywords: extensive reading, english language learners, community service

Copyright (c) 2021 Rini Lindawati

$\triangle$ Corresponding author

Address : Jalan Raya Jabon KM 07 Mojokerto

ISSN 2721- 9224 (Media Cetak)

Email : rinilindawati@unim.ac.id

ISSN 2721- 9216 (Media Online)

DOI : https://doi.org/10.31004/abdidas.v2i4.386 


\section{PENDAHULUAN}

Data UNESCO menunjukkan minat baca masyarakat Indonesia masih sangat rendah. Hal ini terlihat dari indeks tingkat membaca bahasa Indonesia yang hanya 0,001 persen. Artinya dari 1.000 orang Indonesia, hanya ada 1 orang yang memiliki minat dan keseriusan membaca buku. Di kawasan ASEAN, Indonesia menempati urutan ketiga terendah bersama Laos dan Kamboja dalam hal kebiasaan membaca dan menulis. Meski sudah banyak pihak yang menginisiasi dan melakukan sosialisasi terkait kegiatan membaca, nyatanya minat baca masyarakat Indonesia masih stagnan. Kondisi ini diperparah dengan berkembangnya teknologi, mendorong masyarakat untuk lebih memilih mengakses internet dan menonton televisi daripada membaca berbagai bahan bacaan, terutama buku. Pada akhirnya, membaca tidak lagi menjadi bagian dari kebiasaan sehari-hari masyarakat, khususnya pelajar. Untuk itu, harus ada upaya untuk meningkatkan kegemaran membaca siswa.

Bahasa Inggris merupakan salah satu mata pelajaran yang diajarkan di sekolah-sekolah di Indonesia. Bahkan masyarakat Indonesia sudah mempelajarinya dari tingkat taman kanak-kanak. Salah satu aspek yang diajarkan dalam mata pelajaran Bahasa Inggris adalah membaca. Namun, membaca belum banyak mendapat perhatian dari sekolah karena sebagian besar sekolah Indonesia saat ini cenderung memfokuskan pengajaran Bahasa Inggris pada penguasaan tata bahasa dan kosa kata sehingga siswanya tidak memiliki motivasi dan minat membaca yang besar.

Berdasarkan permasalahan yang telah dijelaskan sebelumnya, kegiatan pengabdian kepada masyarakat memulai kegiatan untuk membangun budaya membaca dengan memperkenalkan extensive reading untuk pembelajar Bahasa Inggris. Kegiatan tersebut dilakukan sebagai upaya menggalakkan kegiatan membaca ekstensif dalam rangka meningkatkan kemampuan membaca pembelajar Bahasa Inggris.

Richards dan Schmidt dalam Azmuddin, dkk. (2014) menyatakan bahwa membaca ekstensif adalah membaca dalam jumlah banyak dengan tujuan untuk memperoleh pemahaman bacaan untuk meningkatkan penguasaan kosakata dan struktur bahasa yang nantinya akan mendorong keinginan untuk senang membaca. Prinsip utama membaca ekstensif adalah membaca sejumlah teks yang disesuaikan dengan kemampuan kebahasaan seseorang dengan kecepatan membaca yang disesuaikan dengan keahliannya masing-masing. Pelajar di Indonesia tidak berada dalam lingkungan yang menggunakan bahasa Inggris sebagai bahasa formal atau informal.

Extensive reading yang mencakup skimming, scanning, word-attack skills, vocabulary building, recognising text organisation, interpreting reference, dan inferencing. Keterampilan membaca tersebut sangat berguna dalam memahami teks- teks bahasa Inggris (Hermida, 2019)

Muchtar dan Ali (2017) menerapkan dua metode untuk meningkatkan kemampuan baca mahasiswa. Dua metode yang digunakan adalah intensive reading dan extensive reading. Penelitian ini bertujuan untuk meningkatkan kreativitas belajar mahasiswa dan menjadi tambahan referensi mengajar Bahasa Inggris terutama dalam hal 
membaca bagi para dosen (Muchtar \& Ali, 2017).

Penggunaan bahan bacaan berdasarkan tingkat kemampuan siswa juga dapat menjadi kunci keberhasilan dalam belajar membaca (Harmer, 2007). Senada dengan Harmer, Clarity (2007) mengatakan bahwa pemilihan bahan bacaan berdasarkan tingkat kemampuan siswa atau disebut juga dengan Graded Reader, akan sangat membantu siswa untuk membangun rasa percaya dirinya karena tidak akan mengalami kesulitan dalam memahami isi bahan bacaan. Untuk meningkatkan keterampilan membaca siswa, mereka harus membaca buku yang ditulis dengan tingkat kesulitan yang berbeda dengan penggunaan variasi tata bahasa, kosakata, dan alur berjenjang (Azmuddin, et. al., 2014).

Perlunya kegiatan pengabdian tentang extensive reading untuk pembelajar asing karena untk meningkatkan minat membaca teks berbahasa Inggris mahasiswa dan guru. Kedua, membiasakan mereka untuk membaca teks berbahasa Inggris sehingga kemampuan membacanya meningkat.

Tujuan dari pelaksanaan kegiatan pengabdian ini ialah untuk mengenalkan extensive reading kepada pembelajar Bahasa Inggris, sehingga mereka dapat mengaplikasikan dan dapat mencapai tujuan dari extensive reading itu sendiri yaitu kesenangan membaca teks berbahasa Inggris.

\section{METODE}

Kegiatan pengabdian ini dilaksanakan selama 1 hari yaitu tanggal 29 Desember 2020 secara daring menggunakan platform Zoom Cloud Meeting. Kegiatan dilaksanakan dalam 3 (tiga) tahapan: Pertama, pelaksanaaan pretest menggunakan media Kahoot untuk mengetahui pengetahuan peserta tentang extensive reading sebelum pemaparan materi oleh pengabdi. Kedua, pemaparan materi tentang extensive reading untuk pembelajar asing. Ketiga, diskusi dan tanya jawab tentang extensive reading. Keempat, pelaksanaaan post-test untuk mengetahui pengetahuan peserta tentang extensive reading setelah pemaparan materi. Seluruh tahap ini, disampaikan oleh pengabdi, Rini Lindawati.

Pada tahapan pertama, peserta webinar mengikuti pretest menggunakan platform Kahoot untuk mengetahui pengetahuan peserta tentang extensive reading untuk pembelajar Bahasa Inggris

Pada tahap kedua, metode ceramah digunakan dalam penyampaian materi. Metode ceramah, yaitu dengan memberikan penjelasan dengan berbicara, agar para peserta memperoleh pengetahuan dan wawasan tentang konsep extensive reading untuk pembelajar Bahasa Inggris. Metode ini digunakan untuk menyampaikan materi webinar yang bersifat teori, konsep, dan prinsip dalam extensive reading.

Pada tahap ketiga, metode diskusi dan tanya jawab digunakan. Setelah peserta didik dibekali dengan pengetahuan dan wawasan tentang konsep extensive reading untuk pembelajar Bahasa Inggris, peserta dapat bertanya dan memberikan umpan balik terkait pemaparan materi oleh narasumber.

Pada tahapan keempat peserta webinar mengikuti post-test menggunakan platform Kahoot untuk mengetahui pengetahuan peserta tentang extensive reading untuk pembelajar Bahasa Inggris setelah menerima pemaparan materi dan menjalani sesi diskusi dan tanya jawab. 


\section{HASIL DAN PEMBAHASAN}

Kegiatan pengabdian kepada masyarakat yang berjudul "Extensive Reading untuk Pembelajar Bahasa Inggris" dilakukan secara daring menggunakan platform Zoom Cloud Meeting. Kegiatan ini dilaksanakan pada tanggal 29 Desember 2020. Peserta kegiatan ini sebanyak 45 peserta terdiri dari mahasiswa dan guru Bahasa Inggris di wilayah Mojokerto, Jawa Timur.

Agenda kegiatan pengabdian dilakukan kuis sebelum pemaparan materi untuk mengetahui pengetahuan peserta tentang extensive reading. Dari hasil kuis, menunjukkan bahwa sebagian kecil peserta yang mengetahui tentang extensive reading. Agenda selanjutnya dilakukan pemaparan materi dengan narasumber adalah pengabdi yang berjumlah 1 (satu) orang. Penyampaian materi dari pengabdi, antara lain: (1) pengertian tentang extensive reading; (2) perbedaan extensive reading dengan intensive reading; (3) permasalahan dalam kegiatan membaca bagi pembelajar Bahasa Inggris; (5) manfaat extensive reading; dan (6) kegiatan extensive reading untuk pembelajar Bahasa Inggris.

Penyampaian materi kemudian dilanjutkan dengan sesi tanya jawab mengenai berbagai kendala yang dihadapi pembelajar Bahasa Inggris dalam hal membaca teks berbahasa Inggris. Kegiatan pengabdian kemudian diikuti dengan kuis kedua untuk mengetahui pengetahuan peserta setelah pemaparan materi tentang extensive reading. Dari hasil kuis kedua, menunjukkan bahwa sebagian besar peserta telah mengetahui tentang extensive reading untuk pembelajar Bahasa Inggris.

Dari hasil survei yang dilakukan setelah kegiatan melalui Google Form, lebih dari 95\% mereka menyatakan senang mengikuti kegiatan pengabdian, serta mereka senang mendapat pengetahuan tentang extensive reading untuk pembelajar Bahasa Inggris, serta tertarik untuk mempraktikan kegiatan extensive reading yang dapat meningkatkan kemampuan membaca teks berbahasa Inggris. Hal ini dikarenakan penguasaan bahasa merupakan salah satu hal yang mampu meningkatkan daya saing masyarakat di era teknologi (Tamrin \& Ali, 2019).

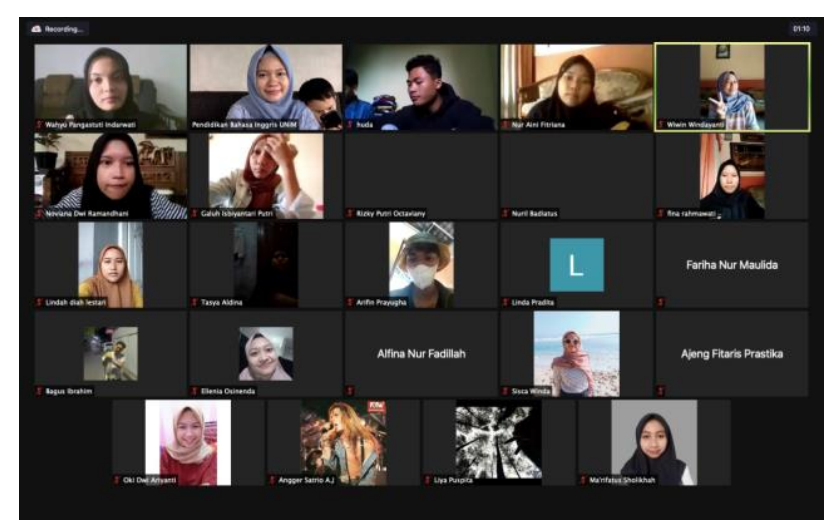

Gambar 1. Kegiatan Pengabdian

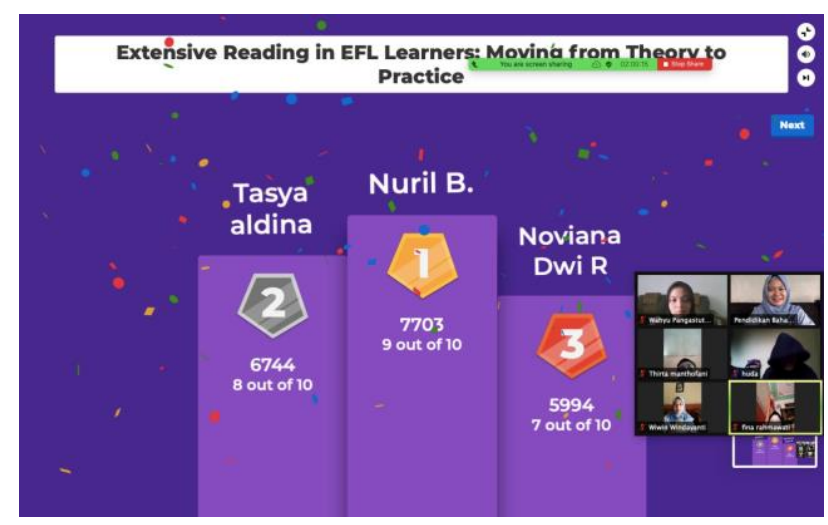

Gambar 2. Kegiatan Kuis

\section{SIMPULAN}

Dari hasil evaluasi capaian kemajuan pelaksanaan pengabdian kepada masyarakat dapat ditarik kesimpulan:

1. Extensive reading untuk pembelajar Bahasa 
Inggris dapat meningkatkan kemampuan membaca peserta.

2. Lebih dari $90 \%$ peserta menyatakan sangat senang dan bersemangat mempraktikan aktivitas dalam extensive reading untuk meningkatkan minat membaca mereka.

Dengan keterbatasan waktu yang dimiliki, tentunya pengabdi menyadari belum maksimal menyampaikan materi tentang extensive reading untuk pembelajar Bahasa Inggris. Pada pengabdian berikutnya, kami menyarankan untuk melanjutkan pelatihan melalui pengabdian kepada masyarakat, sehingga peserta mampu mempraktikkan aktivitas dalam extensive reading dengan maksimal.

\section{UCAPAN TERIMA KASIH}

Kegiatan ini berjalan dengan baik berkat bantuan dan dukungan dari berbagai pihak. Terima kasih kami sampaikan kepada, Rektor Universitas Islam Majapahit, Dekan Fakultas Keguruan dan Ilmu Pendidikan, serta HMP Pendidikan Bahasa Inggris.

\section{DAFTAR PUSTAKA}

Azmuddin, R. A., dkk. (2014). Extensive reading using Graded Reader. International Journal of Research in Social Sciences, 3(8), 109113.

Clarity, M. (2007). An extensive reading program for your ESL classroom. The Internet TESL Journal, XIII(8), 1-6. Retrieved from http://iteslj.org/Techniques/Clarity-

ExtensiveReading.html

Harmer, J. (2007). The Practice of English Language Teaching (4th ed.). https://doi.org/10.1080/03626784.1987.11075 294
Hermida, J. (2009). The Importance of Teaching Academic Reading Skills in First-Year University Courses. The International Journal of Research and Review, Vol3.http://myclass.peelschools.org/sec/12/28291/Homework/article3_v3.pd.

Muchtar, N., \& Ali, G. E. (2017). Penerapan Metode Intensive Reading Dan Extensive Reading Untuk Meningkatkan Kemampuan Membaca Teks Bahasa Inggris Mahasiswa. In Prosiding Seminar Hasil Penelitian (Snp2m) 2017 (Pp. 135-140).

Tamrin, A. F., \& Ali, M. Y. (2019). Pkm Meningkatkan Pembelajaran Bahasa Inggris Bagi Tk-It Fajar Kompleks Mannuruki Berdasarkan Gambar Dan Peningkatan Softskil Remaja Masjid Nurul Ilham Di Kabupaten Maros. Journal Of Techno Entrepreneur Acta, 4(1). Retrieved From https://Journal.Unifa.Ac.Id/Index.Php/Tea/Arti cle/View/75 